University of San Diego

Digital USD

Art, Architecture + Art History: Faculty

Scholarship

Department of Art, Architecture + Art History

10-1-2016

Chinese Glass Paintings in Bangkok Monasteries

Jessica Lee Patterson PhD

Follow this and additional works at: https://digital.sandiego.edu/aaah-faculty

Part of the Asian Art and Architecture Commons, and the Chinese Studies Commons 


\section{Chinese Glass Paintings in Bangkok Monasteries}

A Thai Buddhist monastery, or wat วัด, serves as a dwelling place for monks, a site for ordination, chanting, teaching, and other Buddhist rituals and activities, sometimes funerary services and a place to enshrine the ashes of the cremated, as well as a place where living community members can gather to hear the teachings, honor their dead, participate in ceremonies, donate, and engage in other forms of merit-making. At minimum, the art and architecture of the monastery need only be conducive to such ends, though the tendencies of Thai art are anything but minimalistic. As Justin McDaniel remarks in his insightful treatment of contemporary Thai religious and visual culture, "Generally, in Thai Buddhism 'more is more'. Shrines... are sites of accretion." An aesthetic of abundance (udom sombun อุดมสมบูรณ์) is highly valued.

In their more concrete manifestations, abundance and accretion can take the form of manifold ornaments and elaborations upon the otherwise basic and boxy architectural form of the image halls, the plethora of images and offerings that crowd a typical altar, or the complex and detailed composition of most mural paintings. But these principles of accretion and abundance are not limited only to the intricacy and horror vacui so characteristic of Thai art: they can also account for the presence of objects that, to eyes conditioned by the conventional categories of art history, might appear foreign, secular, or otherwise out of place (Figure 1).

One very distinctive example is the Chinese export art, primarily reverse glass paintings, that can be still be found in a number of monasteries that were built or restored in the second quarter of the nineteenth century in Bangkok (Figure 2). As objects of foreign origin whose presence is best explained by appealing to the predilections of the temples' patrons, these 
paintings can certainly be considered "accretions," but also, in their own status as commodities of a lucrative international trade and often in their imagery as well, these paintings reflect the aesthetic of "abundance" that lends an air of auspiciousness to a monastery.

The preference for Chinese-style art and architecture that was incorporated into the design and decoration of a number of Bangkok monasteries during the first half of the nineteenth century forms a fascinating interlude in the history of Thai art. The monasteries of this era are famous for their architectural innovations, such as simplified rooflines, as well as new designs found in mural paintings, such as "Chinese altar tables" and scenes from Sanguo yanyi (三國演, Romance of the Three Kingdoms; Thai: Samkok สามก๊ก). Many of these are hybrid visual forms, Chinese imagery adapted by Chinese-Thai artists for Thai religious space. Some reverse glass paintings closely resemble the new mural designs, and in some cases may have served as their model or inspiration. This complicates the picture even further, because although the glass paintings were directly imported from China, they were themselves Sino-European hybrids in style, substance, and technique.

To date, the Chinese glass paintings that ended up in the monasteries patronized by the Thai aristocracy have yet to capture the attention and imagination of the scholarly community in the same manner as the architecture or mural paintings of the same temples, despite tantalizing visual correspondences between the glass paintings and some of the murals. Perhaps this is because the glass paintings were imports rather than local adaptations of Chinese art, or else because as "accretions" they are too easily dismissed as distinct from or even ancillary to the material fabric of the buildings that house them and the murals that surround them. However, a closer look at the glass paintings suggests that they were integral components in the Sino-Thai art of Siam's Third Reign (1824-1851), inspiring new aesthetic directions in mural painting and 
reflecting the intimate relationships between Siam and China before trade and diplomacy with Europe took center stage.

One of the few scholars to have discussed the presence of Chinese glass paintings in Thai monasteries is John Clark, in Modern Asian Art. Illustrating his remarks with a photograph of one of the Samkok battle scenes from Wat Nangnong, he alluded to the broad global circulation of glass paintings in the eighteenth and nineteenth centuries and highlighted their role as a vehicle for the "transfer of visual styles" between cultures, as well as the relativization of "low" versus "high" art styles that frequently accompanied their recirculation. ${ }^{2}$ This article will expand on Clark's ideas by connecting them with the glass paintings that can be found in Bangkok, showing how they originated as marketable commodities and subsequently were recontextualized into elite social spaces. It will also show how the glass paintings, on the basis of their origin and imagery, fit into McDaniel's descriptions of a Thai Buddhist aesthetic based on "accretion" and "abundance." After a brief introduction to the history of glass paintings, considerable effort will made to identify and ennumerate the surviving sets of glass paintings in Bangkok monasteries. The role of King Nangklao as an influential patron of Chinese-style art in Bangkok will also be examined. This article will proceed to demonstrate ways that glass paintings might have served as vehicles for the transfer of new images and ideas into Thai temple murals.

Reverse Painting on Glass

"Glass paintings" or "reverse glass paintings," as they are often called, consist of pigments layered to form a picture on the reverse side of a pane of glass. Once the painting is finished and framed, the picture is viewed through the front, unpainted side of the glass, a 
transparent layer that provides protection to the pigments and adds a sleek luminous quality. The technique demands of artists that they lay down the pigments in the reverse of the customary order in which paintings are constructed: the fine details and foreground imagery must be applied initially, and only at the end of the process can the broad strokes of the background be filled in (an exception can be made if the pigments are unusually thin and transparent). The origins of reverse glass painting are distant and obscure; the earliest surviving examples date from the Roman Empire, and there are medieval and Renaissance examples from many parts of Europe. ${ }^{3}$ These early examples tend to be decorative objects, miniatures, or augmentations to other crafts, but from the sixteenth to the nineteenth centuries, glass painting flourished in the form of framed pictures. The current obscurity of reverse glass paintings, together with their usual omission from the standard histories of art, owes much to their widespread association with common rather than elite tastes. By the eighteenth century, a popular application of glass painting was to make color copies of published prints, thus the stigma of unoriginality further eroded the prestige of the medium. $^{4}$

In the eighteenth century, we begin to see references in Europe to the first reverse glass paintings imported from China. Initially, the rarity of these objects made them highly prized: Frieder Ryser notes that "in 1763, an imported Chinese painting $(64 \mathrm{~cm}$ x $38 \mathrm{~cm})$ depicting a lady and a fisherman on a riverbank was assessed at 600 livres in Port Louis," whereas the value of François Boucher's (1703-1770) oil paintings that year did not exceed 350 livres, even though Boucher was already at the height of his career as Rococo's most celebrated artist. ${ }^{5}$ Eighteenthcentury writers were equally uncertain about the precise circumstances through which the medium had taken root in China, speculating that the techniques might have originally been introduced by Jesuit missionaries. ${ }^{6}$ Modern accounts are no less tentative. However they were 
first introduced, glass paintings were soon taken up by the workshops of Canton to supply the export market. Canton (modern Guangzhou) was until well into the nineteenth century the only port permitted to European and American vessels, and the market for these pictures appears to have been predominantly foreign.

The pictures themselves were painted with conventions that owed more to European than Chinese art, such as dramatic if not linearly precise perspective, shading to establish threedimensional forms, and the heavy, brooding foliage characteristic of eighteenth-century English landscape painting. Some glass paintings treated subjects from Chinese history and literature: imagine colorful figures of warriors, scholar-officials, servants or sagely fisherman inserted into backgrounds that combine some of the structural qualities of classical Chinese landscapes with western brush techniques (Figure 3). Others provided a vivid expression for familiar folk genres, such as bird and flower paintings or arrangements of auspicious objects. Some workshops even created explicit copies of Western prints and paintings. New genres emerged, treating subjects of local interest that would have appealed to foreign traders. Especially popular among the seafaring clientele were souvenir views from the small region of China to which foreigners were then restricted: the cities of Canton, Macau, and the Pearl River Delta that connected them. Favorite scenes, such as the river view of the Thirteen Factories in Canton or the sweeping curve of Macau's waterfront, were repeated over and over both on glass and other media until the images became iconic.

Chinese glass paintings are just one format from the diverse category of "export art," which includes not only painted pictures in various media (such as gouache or oils on glass, paper, canvas and other grounds) but a variety of other arts and crafts, such as ceramics and furniture, that China produced in the eighteenth and nineteenth centuries for export to foreign 
countries. The Peabody-Essex Museum in Salem, Massachusetts, a city that was formerly one of the American ports most active in the China trade, holds one of the most extensive existing collections of Chinese export art, including a number of reverse glass paintings. Elsewhere, Chinese glass paintings from the era are scarce and hard to find. ${ }^{7}$ With their mercantile origins and inherent fragility, rarely were they ascribed enough value to merit collection and conservation. A few show up from time to time whenever the major auction houses put together a sale of "Chinese export art," and then vanish again into private collections, usually selling for a modest price. The mostly-anonymous glass paintings have little market value compared to works from established artists, and their aesthetic qualities are not usually of the kind preferred by connoisseurs of either Eastern or Western art. They are implicitly hybrid and commoditized objects, produced by the craftsmen of one region to meet the consumer preferences of another. Yet it is precisely because of these aesthetic deficiencies, the consequences of copying and mass production, that they provide such valuable material evidence for the historian. What images were most favored by the foreign consumers from various nations? What examples of Western art were available to Cantonese workshops at this time? What can we learn about workshop practices by examining the myriad copies of certain standardized or stock images? There is a great deal left to be done in the realm of analysis. This article cannot begin to address all these questions, but hopefully it will demonstrate the opportunities for further research.

To date, Chinese export art has been studied primarily as an artifact of trade between China and Western nations. The research, largely of a historical and descriptive character, has focused on the late stages of chinoiserie, early American entrepreneurship, and the material goods involved in these transactions. ${ }^{8}$ The discovery of numerous glass paintings in the temples of Bangkok demonstrates that there was also an Eastern market for Chinese export art, a 
revelation that adds a new dimension to this field. Where else in Asia were Chinese glass paintings imported, and how were they used? What other countries developed glass painting traditions of their own? John Clark hints at the presence of glass paintings in Japan, the Philippines, Indonesia, and India, and other scholars have located examples in Burma and Northern Thailand. ${ }^{9}$ Research into reverse glass paintings in Asia, whether imported from China or produced locally, is still incipient but ripe for discovery.

\section{Culture Transfer and Relativization}

In Modern Asian Art, John Clark devotes an entire chapter to elaborating the concept of "the transfer" of images and ideas between cultures through the medium of portable art, and Chinese glass paintings are implicated in two distinct spheres of culture transfer. ${ }^{10}$ First, they were produced in southern China, particularly Guangzhou, as part of a larger category of China trade paintings that incorporated a variety of media, techniques, styles, and sometimes concrete imagery from European painting. Subsequently, these already implicitly hybrid objects were circulated back to countries outside China, where association with their place of origin redefined them as genuine specimens of "Chinese" art, taking on the status associated with Chinese culture in the country of destination. Certainly in Siam, we can observe that the Chinese origins of the paintings lent them immense cultural cachet. Whereas in European collections, Chinese glass paintings never rose to the status of fine art, remaining mere souvenirs or collectibles, those that were imported to Bangkok fared much better: they were given a place of great prominence in the decor of eminent palaces and monasteries (Figure 4). Moreover, the fact that glass paintings served as vehicles for the transfer of new forms of "Chinese" imagery that began to appear in Thai temple murals demonstrates that from the viewpoint of the Thai, the authenticity and 
authority of these paintings to serve as exemplars of Chinese art was not in question.

Recognizing glass paintings as an important vector for image transfer between China and Siam in the first half of the nineteenth century provides one key to understanding why the "Chinesestyle" mural paintings that began to appear in Bangkok's monasteries have very little in common with the style of paintings deemed prestigious in China.

Through the importation of Chinese glass paintings to Siam, we can observe not only a distinct example of the transfer of visual styles, but also a process of relativization at play in the many inversions and distortions of status and meaning that attended the project. In China, glass paintings were an unredeemably low-status form of art. One would be challenged to come up with a type of painting more at odds with every value cherished by the elite art discourse of the era. To qualify as elite among the tastemaking Chinese literati, artworks were required to conform to established conventions of style, material, and mythology: elegantly bland and sparsely monochromatic, reverent of past masters yet revealing the spirit of the artist through spontaneous brushwork, painted in albums or scrolls carefully labeled and stored, and, ideally, exchanged through transactions modeled on gift-giving rather than blatant cash trades. The glass paintings, by contrast, were tainted by their color, detail, decorative or narrative content, fixed frames, predominantly anonymous production, and open commodification. So far did they lay outside the elite art discourse in China that they were beneath criticism altogether, dismissed from discussions of fine art as completely as today's art world ignores the "hand-painted" copies of famous paintings that one can order through Chinese websites. In fact, it might not be going too far to identify the glass paintings as an earlier iteration of the same phenomenon, given that a significant portion of the activity of glass painting workshops was directed toward the reproduction of pre-existing imagery, much of it imported from Western sources. ${ }^{11}$ 
In making aesthetic judgments, the aristocracy of early nineteenth-century Siam had little access to the canons of literati taste that dominated elite aesthetic productions in China. Even the wealthiest Chinese residents of Siam had sprung from lower class origins, descendents of immigrants who had left their crowded provinces penniless and with little education, hoping to find better opportunities in the labor-hungry and less populous economies of Southeast Asia. Some got rich, forming a nouveau riche class of merchants who often succeeded at bolstering their wealth with social and political status. By that point, they would have had little opportunity or need for a classical Chinese education of the type that was required to appreciate the literati painting so highly valued in China. As for the Thai, before the latter half of the nineteenth century it was not yet the custom for Thai nobility to travel abroad, so even those intensely interested in Chinese culture, such as King Nangklao (Rama III, r.1824-1951), received impressions of China that were filtered through that country's human representatives in Siam, as well as objects imported through trade. In consequence, the perception of Chinese art that prevailed in Siam was heavily informed by folk culture and imported goods, but little touched by the rarefied scholarly discourse of the Chinese literati. Given that neither the expatriate Chinese merchants nor the local Thai aristocracy in Siam had been indoctrinated into the literati mode of Chinese art criticism, it is easy to understand how the glass paintings achieved a sudden and dramatic relativization of status upon entering nineteenth-century Siam--much like in eighteenthcentury France. These cheap, mass-produced articles of the export trade had only to cross the right borders to be elevated into respectable examples of Chinese art that were deemed suitable for installation in elite spaces, such as the royal palaces of Bangkok as well the capital's most lavish and important monasteries. The recontextualization of these secular commodities into 
royal and religious space provides an especially vivid case of the relativization of a "low" art into a "high" one through the process of cross-cultural transfer.

The eminence of glass paintings in early nineteenth-century Siam was a very unusual occurrence in the broader history of this medium, one that in most times and places has operated as a separate, distinctly inferior sphere of image-making. Even in Siam, it was only for a limited period that glass paintings were collected and displayed in the residences and temples of the wealthy. By the middle of the nineteenth century, Siam's growing trade with the West began to eclipse trade with China, and the new Western turn meant that Chinese designs were no longer so fashionable as before among Bangkok's aristocracy. Chinese art and imagery became less prominent in temple and palace decoration, although it was never discontinued altogether.

Despite the many Chinese glass paintings imported to Siam in the early nineteenth century, this art form did not establish strong roots in the new land. Two prominent exceptions are the use of distinctively Thai designs in glass paintings in the chapel of the Emerald Buddha, as well as framed pictures in Wat Suthat that present ambiguities in regard to their medium, but occupy a similar spatial and decorative niche as the glass paintings in the other temples (Figure 5). ${ }^{12}$ Apart from these sets in very significant state temples, and a few other examples that will be discussed below, there is little evidence of the successful or enduring transplantation of the glass painting tradition to central Siam. Hanging framed paintings over the windows and on the interior columns of temples ceased to be a common practice after 1851, when the Third Reign of the Chakri Dynasty concluded with the death of King Nangklao, suggesting the possibility that this practice was inspired and perpetuated largely by his personal taste. The passing fad for glass paintings among Bangkok's aristocracy was deeply imbricated with the traditional tributary trade relations with China and the aesthetic preferences of the last monarch under whom that trade had 
prospered. As relations with China diminished and the new trends in art and architecture drew inspiration from the West, the decoration of temples and palaces with glass paintings and Chinese-style murals quickly became old-fashioned and at last obsolete. ${ }^{13}$

The Patronage of King Nangklao

Chinese glass paintings hang in the ordination halls (ubosot อุโบสถ) of at least seven Thai Buddhist monasteries in Bangkok: Wat Phra Chetuphon (Wat Pho), Wat Thepthidaram, Wat Nangnong, Wat Phakhininat, Wat Kanlayanamit, Wat Arun, and Wat Suwannaram. ${ }^{14}$ Although diverse in location and appearance, one thing that all these monasteries had in common was a significant degree of patronage by Bangkok's third ruler, King Nangklao (Rama III, r.18241851), and members of his court. Though less widely renowned than his successors King Mongkut and King Chulalongkorn, King Nangklao was a capable administrator who worked to consolidate Siam's regional power through military exploits, tax administration, and foreign trade. He was equally active in cultural affairs, well-known for his fascination with Chinese culture and his extensive patronage of Buddhist works, including the construction and renovation of numerous monasteries. The aesthetic tastes of an absolute monarch can all too easily be elevated into fashions as courtiers strive to emulate the royal example, seeking favor and prestige. ${ }^{15}$ King Nangklao's sinophilia was no secret, and in consequence the Third Reign saw the manifestation of Chinese objects and images throughout Bangkok's public and aristocratic spheres. Not only was the king a major instigator of this trend, but the installation of imported Chinese glass paintings into Thai Buddhist monasteries occurred at the intersection of three of the king's chief interests: China, trade, and temples. 
For years before he was crowned in 1824, the man who would become Bangkok's third king, then titled Prince Chetsadabodin, had a guiding hand on the reins--and more importantly, the purse strings--of the Thai government. He derived a great deal of personal wealth from his role in administering Siam's trade relationship with China. Even before the death of his royal father that precipitated his reign, Prince Chetsadabodin had begun work on what was to become one of his most memorable architectural projects. The story goes that while on a military campaign against Burma in 1820, the prince camped with his army near a certain temple on the outskirts of Bangkok. Noticing that the temple was in disrepair, he pledged that he would restore it if his campaign were successful. His army marched toward the border but found no trace of the opposing Burmese forces. Deeming this sufficient success to merit fulfilling the terms of his vow, upon his return Prince Chetsadabodin began the extensive renovations that would completely transform the appearance of the site. ${ }^{16}$ The temple, at that time named Wat Chom Thong, was conjectured to date originally from sometime late in the Ayutthaya period, probably early to mid-eighteenth century. During its reconstruction in the 1820 s, Wat Chom Thong was renamed Wat Ratcha Orot, the "Temple of the King's Son."

The new, royally-appointed name was matched by a suitably elegant appearance: every building was given Chinese architectural flourishes and painted inside with murals deemed to be Chinese in style. Larger-than-life ceramic soldiers imported from China guarded the doors of the ordination hall, which had been lavishly decorated with mother-of-pearl inlay in a design of fierce dragons cavorting in mist and clouds. At this time, converting Thai monastic architecture to make it look more "Chinese" meant eliminating the characteristic spires, cho fa ช่อฟ้า (sky cluster) and hang hong หางหงส์ (swan tail), from the gable ends of the roof, as well as replacing the typical carved wooden pediments with imagery fashioned from stucco and ceramic mosaic 
(Figure 6). The columns required to support the roof in large image halls (such as in the ordination hall of Wat Pho) were now removed to the exterior of the building, creating a porch around the whole structure. More importantly from an art historical standpoint, the externalization of the columns provided people inside the hall with an unobstructed view of the walls. If these walls were adorned with mural paintings, the images could now be fully appreciated from any point within the building, which might have been one of the aims of this architectural revision. Despite these concessions to the new "Chinese" style, the basic layout and function of the image halls remained unchanged, and the Buddha images they enshrined were unambiguously Thai. For instance, the principle image in the assembly hall (wihan วิหาร) of Wat Ratcha Orot is a large reclining Buddha, a prototype for the enormous one constructed at Wat Pho in the late 1830 s, its head cushioned on a stack of jeweled pillows and flat footsoles similarly adorned with 108 auspicious signs derived from Pali scripture. ${ }^{17}$

Auspicious signs of a very different form and origin dominate the ordination hall of Wat Ratcha Orot, whose innovative murals adapted a form of Chinese folk art in which arrangements of fruit, flowers, and assorted other objects established sly puns and rebuses that expressed good wishes. Compositions of this type have no distinct precedent in earlier Thai art, but were wellrepresented among the glass paintings imported to Siam. Whereas each glass painting frames only a single such arrangement, the murals at Wat Ratcha Orot combine hundreds of them, all uniquely differentiated from one another, into a rough grid that spans the breadth and height of the upper interior walls of the ordination hall. The whole effect is dizzyingly reflected and compounded in the trios of mirrors that hang over each window and door (Figure 7).

Phanuphong Laohasom and Chaiyot Itworaphan offer an innovative interpretation of the relationship between the mirrors and the mural paintings, arguing that the paintings themselves 
should be understood as though they were fragmentary reflections in a row of angled mirrors. ${ }^{18}$ This is a clever and original solution, but to defend it obliges one to wilfully disregard one of the most prominent visual features of the murals themselves, the pains taken by the artists to avoid depicting the same set of objects even twice, much less in multiples. Phanuphong and Chaiyot brush off the objection that the objects in each niche are all unique arrangements, and that none can be identified as a reflection of any other, from any angle, by proposing that the artists did not wish the pattern to become too repetitive. However, throughout their discussion they continually emphasize that it is the chief importance of mirrors, and the mirrors in Wat Ratcha Orot in particular, to reflect--and that these reflections have a moral as well as visual significance. Even if artistic liberty permits one to mirror space without mirroring the objects it contains, it is a much greater stretch to expect the viewer to recognize under these circumstances that mirroring has taken place, where the primary nature and function of a mirror has been so dramatically subverted. Moreover, anyone who has themselves stood before the intersection of a trio of angled mirrors will recall that there is not a single, simple repetition of their reflections of one another, but myriads of like impressions extending and diminishing without limit in multiple directions. Phanuphong and Chaiyot's explanation of the murals is ingenious, but it does not adequately account for what we see.

The artists at Wat Ratcha Orot experimented with crude perspectival techniques to create the illusion of recession, of niches seen from several varying angles, but neither the painted niches themselves nor the objects they contain are mirrored in one another. If no mirroring visibly takes place, then it is difficult to view the niches as anything more than basic depictions of recessive space, albeit oriented at varying angles that shift and alternate across the course of each horizontal row just as Phanuphong and Chaiyot so vividly describe. If this grid-like pattern 
of painted niches, each containing a unique arrangement of auspicious objects, cannot be adequately explained by the idea of mirroring, an alternate proposal is that they are based on the model of a type of curio cabinet (duobaoge 多寶格) that was a popular article in elegant, upperclass Chinese homes during the Qing Dynasty. This manner of display is wholly congruent with the arrangements of auspicious objects that are the principle focus of the Wat Ratcha Orot murals, and can readily explain the decorative, irregular borders of each niche, similar to those seen in many such cabinets. A parallel genre of painting on the same model occurred in Korea in the form of ch'aekkori screens, some of which were even painted using perspectival techniques akin to those at Wat Ratcha Orot. ${ }^{19}$

It remains unclear whether full-scale duobaoge cabinets were ever imported to Siam or manufactured there, though given the large Chinese immigrant population and King Nangklao's own interest in Chinese material culture, this is within the realm of possibility. Even in the absence of actual furniture, glass paintings provided a vector for the transfer of this type of imagery: the sets of glass paintings that we will explore later in this article at Wat Kanlayanamit and Wat Arun are composed as though they were individual niches in just such a cabinet, and the arrangements of auspicious and elegant objects in such paintings share a direct thematic resemblance to those in the murals at Wat Ratcha Orot.

It remains an open question why there are mirrors at Wat Ratcha Orot in the same position that Chinese glass paintings would occupy in several of King Nangklao's later patronage projects. The ordination hall of Wat Phra Chetuphon likewise has trios of mirrors installed over the windows and doors, while featuring reverse glass paintings attached to its interior columns, so these may have been seen as variants of the same aesthetic program. Given the nature of glass painting as a medium, paintings and mirrors were not so clearly differentiated 
as we generally think of them: a significant portion of Chinese glass paintings were painted with mirrored backgrounds that added to their luster and brilliance, although in many cases (possibly even including the set at Wat Kanlayanamit) these mirrored surfaces have lost their clarity over time, clouding and fading so far as to be almost unrecognizable. Phanuphong and Chaiyot observe that given the lack of documentation regarding the mirrors at Wat Ratcha Orot, we are obliged to make speculations based on the existing visual evidence. ${ }^{20}$ The reflective surfaces of the mirrors presently installed in the ordination hall of Wat Ratcha Orot are bright and clean, their excellent condition suggesting that they are not materially of great age, though their presence in trios conforms with Third Reign practice. It seems likely that the present mirrors were installed during a later restoration to replace an earlier set that had suffered extensive damage or attrition. Might there once have even been glass paintings on view? This is speculative, but not entirely without foundation.

Although Wat Ratcha Orot has no glass paintings currently on display, there is at one historical account substantiating that paintings of this kind were in the possession of the monastery during Prince Chetsadabodin's renovations. John Crawfurd, who visited the temple on April 22, 1822, observed:

We were permitted to go over the different apartments without any difficulty. Some portion of the ornaments of that of the prior himself, struck us as odd, if not out of place. These were stiff Chinese copies of English pictures in gilt frames. One, for example, exhibited a fox chase, another the charms of a country life, and the third and fourth were portraits of celebrated English beauties. Many of these are copies of our best prints, and the Chinese, by extraordinary cheapness of price, 
have contrived to disseminate them widely. In Siam they are very frequent, and I have no doubt a traveller would also discover them in the heart of Kamboja, Lao, or Chinese Tartary. ${ }^{21}$

Crawfurd does not state explicitly that the paintings are on glass, but circumstantial evidence suggests that they were: all the other surviving gilt-framed Chinese pictures that were installed in Thai temples during this period are reverse paintings on glass. Glass, too, by virtue of its transparency, was the ideal medium with which to make copies of published prints, and this practice was common not only in China but also integral to the art of glass-painting as it was practiced in Europe.$^{22}$ Among the thirteen glass paintings presently in the ordination hall of Wat Phakhininat are two that appear to be copies of domestic scenes from a European or American source (Figure 8). The British diplomat Henry Burney even saw copies of this kind at the Grand Palace, when in 1825 he was summoned into the presence of King Nangklao. According to Burney, when he entered the Hall of Audience he observed that "to each pillar was affixed a large Chinese painting on glass of a European officer or Lady."23 That Chinese glass paintings ornamented the audience hall in the royal palace during King Nangklao's reign further strengthens the suggestion that it was the king's preference for these paintings that led to their installation in a number of the monasteries that he patronized.

It is notable that both Crawfurd and Burney specified that the paintings they saw portrayed Western imagery, even though they recognized that they were Chinese copies. Were Chinese glass paintings that replicated European and British images especially in vogue in Siam in the early years of King Nangklao's reign, or do these simply happen to be the images that most readily caught the eye of Western visitors and moved them to comment? It is well- 
established that a substantial part of the output of glass painting workshops in China consisted of such replicas. Carl Crossman notes that most of the European prints copied by the Chinese artisans had originally been published after the 1780s, giving us a rough sense of when this practice of copying began to thrive in China, having found an eager market in the foreign traders at Canton. $^{24}$

Josef Vydra reports that in Eastern Europe, reverse glass paintings had long been sold as souvenirs from pilgrimage sites. ${ }^{25}$ We can find a parallel practice in the popularity of glass paintings among the European and American traders in China, who appear to have been the primary market for these commodities. Although the motivations of most men who went to trade at Canton were commercial and secular, reverse glass paintings were nevertheless deemed an attractive trophy of their arduous journey and exotic destination. Among the widely varying types of imagery in glass paintings, one popular theme consists of landscapes and landmarks from the Pearl River Delta, the hub of the China trade, including such scenes as the city of Macau, Whampoa Harbour, and the Thirteen Factories of Canton (Figure 9). Intriguingly, amid the dozens of Eastern European glass paintings rich with Christian iconography illustrated in Vydra's book, one image stands out starkly from the rest. From the collection of the Ethnographic Museum in Pilsen, labeled Secular picture. Harbour (supposedly Lisbon) in 1870, it is unmistakably an image of the Thirteen Factories in Canton, strikingly similar to pictures of the same scene that can be found at Wat Pho in Bangkok. ${ }^{26}$ In this example, only four of the six national flags normally represented in this stock scene are shown over the factories, and the order of the flags is unconventional. These details, together with the late date and the mis-identification of the harbor as that of Lisbon (curiously teeming with Chinese junks) raises the possibility that the anomalous glass painting might not itself be a Chinese import, but a later European copy of 
one. Because the transparency of glass facilitated the copying of other images or standardized templates, the oeuvre of glass paintings abounds with copies. In many cases the glass painter copied from published engravings, which as Wolfgang Steiner points out were themselves usually copies of oil paintings or even of prior engravings, and glass painting workshops churned out many multiples of stock images that were known to sell well, such as the ubiquitous river view of the Thirteen Factories in Canton, one of the most iconic images of the China trade. ${ }^{27}$

\section{Glass Paintings of the Pearl River Delta and Romance of the Three Kingdoms}

Wat Pho, more formally titled Wat Phra Chetuphon, is arguably the most central and prestigious monastery in Bangkok. Located directly adjacent to the Grand Palace, Wat Pho was constructed as a religious complement to the royal edifice at the time when Bangkok was first designated the capital in the late eighteenth century. Not only has this monastery enjoyed a continuous history of royal patronage since the beginning of the Chakri dynasty, it also contains Bangkok's richest trove of Chinese paintings on glass. The sixteen interior columns of the ordination hall are each hung with a trio of paintings featuring landscapes from around the Pearl River Delta and scenes from Romance of the Three Kingdoms. Strikingly, due to the proliferation of copies within this single set, the forty-eight paintings consist of variations on only nine different types of scene. One trio appears be a modern replacement copied from the one on a neighboring column, so this analysis will address only fifteen of the sixteen trios. ${ }^{28}$

The Pearl River delta scenes are paired at the base of each trio of paintings, their arrangement demonstrating a distinct preference for pairing images of the same type, emphasizing their similarity rather than trying to minimize the prevalence of copies (see Figure 9). Of the fifteen groups, twelve use matched pairs for the bottom two images. The thirty images 
that form the base of the fifteen trios comprise the following: eight paintings of small boats flying Danish colors in a short canal in a foreign enclave; six paintings of the Thirteen Factories at Canton; six portraits of various ships, mostly British, of which two are early-model hybrid steamers that have not yet dispensed with full rigging; three views of the Macau waterfront looking across the Praya Grande; three views of Macau from its narrow isthmus; two paintings of the Dutch Folly, a fort in the river near Canton; one of a seaside Chinese temple, possibly at Macau; and one anomalous painting of cavorting mythical animals. With the exception of the ship portraits, which show more variation (and might have been copied from pre-existing Western works, as the painted border of matting in several images strongly suggests), the paintings in each group are close copies of one another, differing only in trivial details such as the number and arrangement of human figures or vessels in the water. The prevalence of so many near-identical compositions indicates the likelihood of workshop production in which artists based each scene on stock templates, a practice for which glass painting was ideally suited.

The Thirteen Factories at Canton and the view across Macau's Praya Grande were both especially popular scenes that were widely reproduced in a variety of media during the early decades of the nineteenth century. The versions at Wat Pho, although conforming to the standard compositions, appear to be rather late and clumsy additions to this body of imagery, produced by a workshop that promoted quantity over quality. In the collection of the Peabody-Essex Museum is a glass painting, dated to the last decade of the eighteenth century, that appears to be a direct forebear of Thirteen Factories composition found at Wat Pho, although of much finer workmanship (Figure 10). The composition is distinctive for taking artistic license with the scene, including a partial view of the Dutch Folly and a pagoda on a distant hill, both famous 
views of Canton but not actually visible from that vantage. The Wat Pho paintings reproduce and even exaggerate these accretions. Similar distortions characterize the Macau waterfront scenes, in which the ships and buildings can loom so large as to make the Praya Grande almost unrecognizable to eyes accustomed to a more naturalistic panorama (Figure 11). A similarly cramped and disproportionate view of Macau can be seen in the gilt and lacquer decoration on the cover of a sewing table, also in the collection of the Peabody-Essex Museum, that was made in China and exported to the United States in the early nineteenth century. ${ }^{29}$ Although the Wat Pho paintings are stylized to a greater extent, the arrangement of buildings, bay, hills and forts is consistent with the standards for this view of the Praya Grande.

Why were images from the Pearl River Delta, nineteenth-century China's commercial hub, so prominently placed in Wat Pho's ordination hall, the monastery's most sacred space? First, it should be pointed out that the juxtaposition is less striking than it might appear to Western eyes conditioned by Christian qualms about mixing money with religion. Although the vinaya prohibits Buddhist monks from the acquisition of individual wealth and private property, Buddhist laypeople are subject to no such strictures, and the monasteries can accumulate funds on behalf of the monks who reside there. Indeed, the more prosperous--and generous--the lay Buddhists, the more the monasteries they support will flourish. When a layperson donates a portion of his or her wealth to the temple, it is understood to be converted to spiritual merit for the donor, while in material terms it functions to create a more beautiful and comfortable environment for religious practice. This is operation is implicit behind the theory of "abundance" articulated by McDaniels as one of the key aesthetic traits of Thai Buddhism.

The second trait, "accretion," referring to the idiosyncratic objects that tend to accumulate in temples as a consequence of such donations, is closely related. "Accretion" also serves to 
highlight the relationships of individual patrons to the monastery: again in contrast to Western practice, little value is attached to donating anonymously, so Thai temples are replete with signs and placards specifying precisely who gave what, or how much, and in the case of material objects, the taste of the donor is sometimes reflected in the gift.

Considered in relation to the principles of "abundance" and "accretion," the Pearl River Delta paintings are a perfect fit for Wat Pho: it was King Nangklao's profitable trade relations with China that supplied him with the wealth to renovate so many monasteries, including Wat Pho, during his twenty-seven year reign. It wasn't only wealth that flowed back to Siam, but material goods of all kinds, many of which found their way into the monasteries' material fabric: construction materials of ceramic and stone, Chinese cement statues (tukata jin ตุ๊กตาจีน) of people, animals, or pagodas that fill the courtyards of so many central Bangkok monasteries, and of course the glass paintings themselves. The Pearl River Delta scenes at Wat Pho are unusual only in that they so transparently reflect their origin, hinting at the commerical relationships that brought them to Siam in the first place.

At the apex of each trio of paintings installed on the columns of Wat Pho's ordination hall are fifteen works that, although similar in size, style and palette to the Pearl River Delta scenes hung just below them, present us with a different genre that might appear even more incongruous in the setting of a Buddhist temple (see Figure 9). Each one is a battle scene, dramatizing the conflict between a small group of five or six Chinese warriors. Dressed in colorful armor that looks more theatrical than practical, brandishing sabers, spears, flags and pennants, in each case two or three of the warriors are mounted and engaged in challenging one another, while their subordinates support them on foot. Domed white tents crowned with round red tufts crowd the edges of the scene; the backgrounds consist of unpeopled wilderness landscapes given definition 
by loosely-defined trees and hazy distant mountains. Curiously, even though at a glance all the battle scenes are so similar as to be almost indistinguishable, upon close inspection there is as much variety here as in Pearl River Delta paintings: between the fifteen paintings there are four pairs of copies, one group of triplets, and four paintings that are unique, yielding a total of nine discernible templates used as the basis for the scenes. The story in which these warriors play a part is easily ascertained, and characters on the flags confirm it: these are battle scenes from Sanguo yanyi, in English better known as Romance of the Three Kingdoms, and in Thailand called simply Samkok.

Nineteenth-century Siam was a society exquisitely sensitive to vertical hierarchies: relative status relationships between what was "higher" and "lower," both in the material and in the abstract, governed social, physical, and religious space. The position of the Three Kingdoms scenes at the top of each trio implies that they were valued even more highly than the Pearl River Delta paintings. Circumstantial evidence also points in this direction. The absolute monarchs of old Siam enjoyed every privilege in their country but that of leaving it, so they could only experience China through its art and literature, not through direct observation. Three Kingdoms imagery in a variety of media was a popular theme of palace and temple decoration in the early nineteenth century. ${ }^{30}$ The Chinese epic novel had been translated into Thai just two generations earlier, in the court of Rama I (r.1782-1809), Bangkok's founder and King Nangklao's grandfather. Its popularity had peaked in ensuing years, and King Nangklao, the notorious sinophile, appears to have been a particular fan. The presence of Three Kingdoms glass paintings at Wat Pho links it with three other royal monasteries built or renovated during his reign, Wat Thepthidaram, Wat Nangnong, and Wat Phakhininat, which possess similar works. 
The ordination hall of Wat Thepthidaram was constructed between 1836 and 1839, so the glass paintings might already have in place when Sunthorn Phu, Siam's greatest poet, ordained there in $1840 .{ }^{31}$ Presently five paintings still remain, hung singly on the ordination hall's interior columns. A trio of empty frames still installed over one door suggests that the set was perhaps once much larger, but gradually depleted through breakage or loss. The surviving paintings are all scenes from Three Kingdoms, and they share the same scale, palette, and representational conventions as the pictures on this theme from Wat Pho. Only one of the five is a battle scene, indistinguishible in kind from the Wat Pho paintings though not identical in composition to any of them. The rest show quieter moments from the story, of which the most recognizable is an event from Chapter 70 in which one of the heroes distributes wine throughout his camp in order to create an impression of lax discipline that will lure the enemy into attacking, meanwhile secretly preparing an ambush (Figure 12). Among the five are a single pair based on the same template, a courtyard scene, in which the colors and patterns differ slightly but the compositions are otherwise identical. The creativity of the artists in glass painting workshops was not completely stifled: as long as they followed the templates that specified the basic compositions, they could add their own flourishes in the extraneous details.

While the Three Kingdoms glass paintings at Wat Pho and Wat Thepthidaram appear, based on similarity of style and palette, to have originated from the same workshop, those at Wat Nangnong are a mixed set. ${ }^{32}$ Like Wat Ratcha Orot, Wat Nangnong adopted the new architectural convention of banishing the roof-supporting columns to the exterior porch, so the paintings are hung over the windows and doors. They are hung in trios, not stacked one over two, as at Wat Pho, but side by side, with a larger central painting flanked by two smaller ones, the same arrangement as the mirrors at Wat Ratcha Orot. The collection has been much diminished 
by time: judging from the placement and the number of surviving empty frames, there were originally at least twenty-seven paintings arranged in nine trios. Today, only fifteen remain intact in their frames. Although a couple of the smaller paintings are indistinguishable in style from the Three Kingdoms paintings at Wat Thepthidaram and Wat Pho, the larger ones, while sharing the same representational conventions--the camel-nosed horses, the red-knobbed tents, the fluttering pennants and flowery armor of the warriors--display greater complexity of composition and skill in rendering (Figure 13). ${ }^{33}$

We might speculate that King Nangklao reserved these superior versions of the Three Kingdoms paintings for Wat Nangnong, another temple that he extensively patronized, in keeping with his plan for the temple's overall decoration. The vast upper wall murals depict the tale of the Buddha's conversion of the pompous King Jambupatti, before whom the Buddha manifested in the form of an even greater celestial king. The Buddha image on the altar, adorned with kingly regalia, reinforces the theme of story, as do the royal ceremonial implements painted in gilt lacquer on the window frames. ${ }^{34}$ But Wat Nangnong reveals the Thai genius for assimilating elements of foreign culture and instilling them with local meaning: on the strips of wall space between the windows are colored gilt lacquer (an artistic technique called kammalor กำมะลอ in Thai) murals of additional scenes from Three Kingdoms. This demonstrates that Three Kingdoms was not just an arbitrary story for which glass paintings happened to be available: it meant something to the king, and he installed them deliberately as a coherent element of the ordination hall's decoration. As elements of temple decor that better reflect the idiosyncratic tastes of a particular patron than conventional Buddhist imagery, the Three Kingdoms paintings in Third Reign temples operate as distinct examples of accretion. 
Glass Paintings and Image Transfer

To what extent did the glass paintings serve as a medium for the transfer of Three Kingdoms imagery to Siam? This is a difficult question to address because of the enormous popularity of this story during the nineteenth century, enjoyed by the Thais in a variety of media including literature, theatre, and the visual arts. The appeal of the story was driven in part by the large influx of Chinese immigrants, and in part by the favor of the royal court. Temples patronized by both groups were sometimes adorned with Three Kingdoms imagery during the Third Reign. Wat Nangnong, for instance, contains scenes from the story in two different media and styles, the glass paintings hanging over the windows and the gilt lacquer murals between them. The former are vibrant, colorful, and focus on characters and their activities. The latter, restrained by technique to a more limited palette of gold and black highlighted with subtle red and blue washes, emphasize the architectural and spatial environments of each scene. Glass paintings, then, seem to have been just one conduit for image transfer among a broad and varied influx to Siam of Three Kingdoms imagery from China that must have included performances, printed books, and the mental schema carried by living artists.

Like the glass paintings themselves, elite patronage of The Romance of the Three Kingdoms in Siam led to the elevation of its status. While the story was one that could be enjoyed across all levels of society, royal sponsorship of the Thai literary translation meant that Romance of the Three Kingdoms rose in prestige from a mere popular tale to one associated with both consumption and production by the royal court. As if to underscore this connection, in addition to the four monasteries with Chinese glass paintings that prominently feature Three Kingdoms imagery, similar paintings can also be found in at least two palace buildings ${ }^{35}$ For instance, hanging casually amid other domestic decorations in the Vimanmek mansion, a former 
royal residence, is a glass painting depicting a battle scene from Romance of the Three Kingdoms that is strikingly reminiscent of those at Wat Nangnong. A larger set can be found at the Ho Phra That Monthian in the Grand Palace, a temple-like space that enshrines the ashes of deceased kings from the early Bangkok era, including those of King Nangklao himself. Here, the glass paintings hang over the windows, just as in Wat Nangnong and other temples, but the raised altar at the far end of the room bears not a Buddha image but three golden urns representing the first three kings of the Chakri dynasty. Firm boundaries between the royal and the religious are not clearly differentiated in Thai tradition, where both domains require the use of a special reverent vocabulary that sometimes overlaps, where palace and temple buildings historically enjoyed similar architecture and ornamentation, and where historical kings have become objects of cultic worship in their own right. ${ }^{36}$ At both Wat Nangnong and the Ho Phra That Monthian, we can observe the glass paintings operating on the slippery boundary between royal and religious space.

The ordination hall of Wat Phakhininat, another of King Nangklao's restoration projects, displays thirteen Chinese glass paintings hanging singly over the windows and doors. ${ }^{37}$ Several of the scenes portray events from the Three Kingdoms tale, easily recognized from the distinctive appearance of the three main heroes: Liu Bei, pale and elegant; Zhang Fei, swarthy and hairy; and Guan $\mathrm{Yu}$, with his ruddy complexion and long silky beard (Figure 14). These are not generic battle scenes, but complex narrative moments handled with artistic skill, in all particulars resembling the larger central paintings of the trios at Wat Nangnong. The set of glass paintings at Wat Phakhininat is not limited to Three Kingdoms scenes, however. Similar in size and style but differing in theme are a number of other scenes drawn from Chinese history and literature, such as an image of a scholarly gentleman that, with the blessing of a visible inscription, can be 
identified as the Tang Dynasty calligrapher Zhang Xu. The two paintings from this temple that replicate a European source image have already been discussed above (see Figure 8).

Wat Phakhininat is distinctive for bearing the imprint of King Nangklao's distinctive tastes not only in the display of Chinese glass paintings, but also in the unusual mural program. The murals in the ordination hall demonstrate further development of the designs that first appeared at Wat Ratcha Orot. They still consist of arrangements of auspicious objects, but instead of dazzling the eye with numerous compositions in individually painted cells, Wat Phakhininat scales back to a single large composition occupying each bay between the windows and doors (Figure 15). Whereas the configurations of auspicious objects at Wat Ratcha Orot are still closely derivative of Chinese rebuses, those at Wat Phakhininat teem with an assortment of motifs that, though potentially infused with significance as visual puns, here seem to have been chosen haphazardly for aesthetic effect. ${ }^{38}$ The most important change, however, is the way that the artists have de-emphasized the significance of these objects by visually subordinating them to the fanciful tables and stands that dominate each composition. The tables are constructed on a squared scrollwork meander pattern that play fancifully with planes and angles, in some cases performing Escher-like and impossible perspectival feats. In the earlier murals at Wat Ratcha Orot, such meander tables were frequent but far from ubiquitous, whereas at Wat Phakhininat they supply the essential structure of the compositions, their twists and turns directing the movement of the eye (see Figures 7 and 15). The most common Thai name for this design, toh bucha baep jin โต๊ะบูชาแบบจีน, or "Chinese altar tables," reflects the new prominence of the tables over other elements, such as vases of flowers, that once held more significance for their semantic content. The puns were only operative in Chinese, of course, and unlike their visual apparatus, could not be imported into Thai. Where a knowledgable Chinese viewer might have 
discerned auspicious messages, the Thai viewers saw offerings placed upon an altar, and named the design after this interpretation.

It is often difficult to pinpoint the precise channels through which imagery is transferred between cultures. Arrangements of auspicious and elegant objects were common enough in Chinese crafts, folk art, and domestic decoration, but how did these images reach Siam? Did they arrive as mental templates with the numerous Southern Chinese immigrants who supplied Bangkok with a ready supply of cheap labor during the Third Reign? King Nangklao did not disguise his preference to employ Chinese laborers in the construction of his temples, and the sure hands that inscribed characters in the mural paintings suggest natively-acquired literacy. ${ }^{39}$ While we cannot discount the possible influence of living expertise, difficult to trace in the typically anonymous, unsigned temple murals, there is also a material link. Surviving sets of glass paintings at two Bangkok monasteries, Wat Kanlayanamit and Wat Arun, reveal a concrete proximate source for the compositional types that inspired the "Chinese altar tables" (toh bucha baep jin) design in Thai mural painting.

\section{Glass Paintings of Elegant and Auspicious Objects}

On the west bank of the Chao Phraya River, the main artery running through Bangkok and once the epicenter of Sino-Siamese trade, stands a monastery with strong historical ties both to King Nangklao and to the Chinese immigrant community. It was originally constructed by Chao Phraya Nikonbodin, a government official who, despite his prestigious Thai title, was a full-blooded Hokkien (Fujianese). He assisted Prince Chetsadabodin, as King Nangklao was called before his coronation, in the management of the China trade during the reign of the prince's father, Rama II (r.1809-1824). Both men achieved great profit and prestige in this 
endeavor. Early in the Third Reign, Chao Phraya Nikonbodin expressed his gratitude to his royal patron by constructing a monastery in the Sino-Siamese architectural style that had been developed just a few years earlier at Wat Ratcha Orot. Upon completion, he dedicated the whole site to the new king, who expressed his approval by building a magnificent new assembly hall (wihan) in between the two original image halls, bestowing the name "Wat Kanlayanamit" (Temple of the Beautiful Friend) upon the monastery, and granting Chao Phraya Nikonbodin the right to use "Kanlayanamit" as his surname, inheritable by his descendents. ${ }^{40}$

In the ordination hall of Wat Kanalayanamit are seventeen reverse glass paintings hung in six trios over the windows and doors--the odd number because, as elsewhere, loss has rendered one of the trios incomplete. Whereas the reverse glass paintings we examined in Wat Pho, Thepthidaram, Nangnong, and Phakhininat demonstrated enough similarities to raise the possibility of a common workshop origin, the physical qualities of those at Wat Kanlayanamit suggest a different source. The compositions are formatted in a vertical rather than horizontal orientation, the frames are ungilded, and it is clear that quite another set of pigments was used. The paintings we have considered so far have retained most of their brilliance and luster, but those at Wat Kanlayanamit have faded dramatically. Peonies, chrysanthemums, and their foliage have all withered to various drab shades of brown, while olive green peaches compete with graying Buddha's hand citrons for the most unappetizing hue (Figure 16). The only colors that shine vividly out of these paintings are red, white, and sparingly applied highlights of blue.

Despite the depredations of age, the glass paintings at Wat Kanlayanamit could serve as one of the most valuable clues we have to explain the origin of the "Chinese altar table" design that first appeared in the mural paintings at Wat Ratcha Orot and were subsequently implemented at Wat Phakhininat. Vases of flowers and dishes of fruit with traditional auspicious 
meanings, particularized by connection with other meaningful objects such as coral branches and lingzhi 靈芝 fungus, form the basis of the Wat Kanlayanamit compositions, a genre that in Chinese can be described as zabao 雜寶, “assorted treasures.” The larger central painting of each trio is even garnished with the distinctive squared scrollwork of bright red meander tables. All of these elements found their way into the murals at Wat Ratcha Orot and Wat Phakhininat, together with an encyclopedia's worth of extras, an artistic enthusiasm that overwhelms the underlying semantic component of any given rebus (see Figures 7 and 15). We cannot know if the glass paintings at Wat Kanlayanamit were the specific objects that inspired murals of this design on the walls of other temples, but knowing that glass paintings of this compositional type were mass produced for export in China, and imported to Bangkok for the decoration of temples, does establish one explicit channel through which the zabao designs reached Siam and commanded the attention of temple patrons.

Deep within the mazy alleys in the southeastern part of Bangkok's Chinatown hides an architectural treasure: an intact courtyard home built by a wealthy Chinese family in the midnineteenth century, the Posayachinda residence. The aggressive drive for development in Bangkok has meant that very few such early domestic structures have survived, unlike the temples and palaces whose sacred auras have protected them from casual destruction. The Posayachinda residence presents us with a rare glimpse of another way that Chinese glass paintings were used in nineteenth-century Bangkok: in the room that contains the ancestral altar, five glass paintings are affixed to the roof beams directly overhead, a central trio flanked by single pictures to the right and left (Figure 17). ${ }^{41}$ The paintings and their frames have an uncanny similarity to those at Wat Kanlayanamit, so much so that initial inspection suggests they might originally have been part of the same set, but close inspection reveals slight differences. Whether 
or not they share an identical origin, the Posayachinda paintings demonstrate that Chinese families in nineteenth-century Bangkok sometimes imported glass paintings for private use. The way the paintings are positioned over the ancestral altar, the most eminent and spiritually charged location in the house, parallels their installation within the sacred space of the ordination halls in Thai monasteries.

Wat Arun may be the most widely recognized of Bangkok's monasteries: popularly called the Temple of the Dawn, its silhouette is one of the city's most iconic images. The magnificent prang (Khmer-style redented spire) that graces so many postcards was completed by King Nangklao, who chose to have the outer surface of the 200 foot tower and its subsidiary spires adorned with a vast ceramic mosaic, many pieces Chinese in origin. The king likely also had a hand in importing the numerous large Chinese statues that ornament the grounds. Artifacts of the China trade appear even in the ordination hall, where yet another set of glass paintings is installed. In materials and composition, the eighteen glass paintings at Wat Arun are sufficiently different from the sets at Wat Kanlayanamit and the Posayachinda residence to suggest a separate supplier, but the scenes are constructed from the same basic components: vases of auspicious flowers, dishes of auspicious fruit, assorted scholarly objects and elegant collectibles, and ornamental meander tables of squared scrollwork (Figure 18). There is one notable distinction, however: the Wat Arun paintings are inscribed with text, and these labels provide valuable insight into what the Chinese artist wanted to identify as important about the scene. In each case, the inscription ignores the more colorful and visually appealing elements of the composition to focus on the drabbest, most inconspicuously painted object: typically it is an antique bronze vessel that is highlighted by the text as the proper focus of our attention. We might therefore categorize the set of paintings at Wat Arun into a slightly different genre from 
those at Wat Kanlayanamit: rather than zabao (sundry treasures), the term bogu 博古 (extensive antiquities) might be a better fit. These granular distinctions would likely have been lost upon Thai viewers, however, most of whom could not read Chinese. If one disregards the written labels, the paintings produce a very different effect upon the eye: the more colorful and exuberant objects take precedence over the quietly dignified bronzes. Once again, the most visually captivating detail turns out to be the one with the least symbolic or semantic significance to the original work, namely, the fanciful and ubiquitous meander tables.

One of the most distinctive aesthetic innovations of King Nangklao's reign was the adaptation of zabao and bogu designs resembling those from imported glass paintings into the "Chinese altar table" design in Thai temple murals, making the meander table the central visual element. In addition to Wat Ratcha Orot and Wat Phakhininat, there are a handful of other monasteries, as well as one structure in the Grand Palace, that use Chinese altar tables as a primary mural design on the lower or upper walls. ${ }^{42}$ More widespread and long-lasting was the use of this design as a secondary design on window and door panels or their reveals, in which capacity it can be observed at a number of very important temples, including Wat Pho, Wat Suthat, and Wat Bowonniwet. That the design only achieved widespread use in these subordinate positions was a natural development, given the general preference in Thai mural painting to employ narrative scenes in the more prominent eye-level wall spaces.

\section{Glass Paintings of Birds and Flowers}

In Siam during the Third Reign (1824-1851), there were a great variety of patterns used to decorate the windows and doors of temples. Chinese altar tables, guardian figures of various ethnicities, and nature imagery were popular options. Some manifestations of nature imagery in 
Thai murals suggest stylistic derivations from Chinese art, in particular the "bird and flower" pairings that have long been an established genre of Chinese painting. Because bird and flower imagery tends to be much more generalized and variable than the distinctively meander-shaped "Chinese altar tables," it is more challenging to determine if imported glass paintings played a role in the transfer of Chinese bird and flower imagery to Thai temple walls. Nevertheless, that such models did exist as a visual resource available to artists is demonstrated by the set of glass paintings at Wat Suwannaram.

Renovated by King Nangklao in the first decade of his reign, the ordination hall of Wat Suwannaram is famous for the mural paintings by Luang Seni Borirak (Khong Pae) and Luang Wichit Chetsada (Thong Yu). Their royally-appointed titles, together with the fact that their names are still remembered and celebrated (in contrast to the majority of the era's mural artists whose identities have been lost to history), attests to the renown that this pair enjoyed even in their own lifetimes. The murals of Wat Suwannaram are as good a candidate as any for what we might call the "conventional" temple mural program of the Bangkok era: there is a diagram of the cosmos on the upper wall behind the Buddha image, facing a manwichai มารวิชัย (maravijaya, victory over Mara) composition on the opposite wall, with jataka narratives (stories of the Buddha's former lives) on the lower walls between the windows and doors. The upper side walls are painted with horizontal rows of celestial beings, all devoutly facing the direction of the Buddha image, a pattern called thep chumnum เทพชุมนุม (congregation of angels). The door and window panels feature pairs of guardian figures. Over the windows and doors hang a set of Chinese glass paintings, the only element of the temple decor that is not characteristically Thai in conception and execution. 
Of the twenty-one glass paintings at Wat Suwannaram, apparently remnants of a much larger set that once hung in trios over the windows and doors, twenty are bird-and-flower (Chinese: huaniao) scenes. Painted in vivid blue, red, green, white, and the oxidized traces of what might once have been yellow, the imagery is set against a solid black background color that allows the pictures to harmonize surprisingly well with the dim, earthy tones of the wall murals (Figure 19). In form, composition, and palette, they closely resemble the more intact set of bird and flower paintings in the Reclining Buddha wihan of Wat Pho. Each scene consists of one or more pairs of birds of the same species, whose plumage often demonstrates a differentiation of sex within the pair. The types of birds range from mythological phoenixes to colorful but mundane breeds such as pheasants, parrots, and various blue birds--with a distinct preference for types that could accommodate the preferred colors of the artist's palette--amid a luxuriant growth of now-faded peonies and other flowers. These twenty bird and flower scenes are remarkably similar to one another, but close inspection reveals only one case of a shared template. The central picture of the surviving trios is always slightly larger than the two on either side, much like the arrangement at Wat Nangnong. This ordering into threes with visual emphasis on the center is paralleled by the glass paintings over the three doorways in the end wall facing the Buddha image, as well as in relative heights of the doorways in relation to one another (see Figure 1). The central painting over the central doorway, the most visually prominent of all the glass paintings, is the single image in Wat Suwannaram's set that is not a bird and flower composition. Instead, it is a vertical landscape in a hybrid European-Chinese style whose lower portion accommodates a narrative episode in which an elegantly appointed procession approaches a white-bearded fisherman (see Figure 3). It is possible that the flanking doors had always been hung with a single image rather than a trio, in order to enhance the impact of the 
arrangement whereby a larger central object is flanked by two smaller ones, characteristic of the doors as well as the glass paintings on this wall.

It is difficult to say to what extent the glass paintings at Wat Suwannaram might have impacted local mural painting practices. Whereas the glass paintings featuring "Chinese altar tables" and scenes from Romance of the Three Kingdoms reflected new themes that began to appear in Thai temples murals during the first half of the nineteenth century, bird and flower imagery was already well-entrenched in Thai art. Bird and flower scenes rarely, if ever, constitute the primary mural program on temple walls, but such imagery remains a popular choice for window and door panels or reveals, or for enlivening the background of narrative scenes.

Accretion and Abundance

Despite the importance of glass paintings as channels of culture transfer as Siam sought new artistic ideas and motifs from China, it is important to bear in mind that paintings of this kind were atypical in the context of Thai Buddhist monasteries in Bangkok. While there are undoubtedly additional sets waiting to be discovered, to date sets of Chinese glass paintings (not counting mirrors, screens, or paintings that might have been made locally) have been located in just the several monasteries described above, as well as a few palace buildings and private residences. Few of the glass paintings portray explicitly Buddhist imagery, which raises the question of how these objects could have been construed as appropriate or meaningful within Thai sacred space.

One possibility was raised in the discussion of Wat Nangnong, where we saw that the Three Kingdoms glass paintings complemented the theme of royalty that was communicated by 
the Buddha image, murals, and decorative painting in the same temple. Their presence testified to the popularity of the Three Kingdoms story in the Thai court, and hinted at the flow of goods through Sino-Siamese trade channels that linked the small state of Siam with the mighty Chinese empire. More broadly speaking, Chinese glass paintings in the temples built or renovated by King Nangklao served as a reminder of his patronage, as the ruler principally associated with the China trade as well as the numerous Bangkok temples that he built or renovated with elements that were deemed Chinese in style. Through this richly layered associative process, the Chinese glass paintings can be interpreted as "accretions" to Thai sacred monastic space, using McDaniel's terminology. Although the glass paintings portraying scenes from the Pearl River Delta, Three Kingdoms, or arrangements of Chinese auspicious objects appear to be anomalous objects with no clear connection to the core rituals or principles of Theravada Buddhism, their value does not lie in their direct significance or symbolic meaning, but rather "in their association with other images and with the people who... gave them." ${ }^{43}$

McDaniel's articulation of the importance of "abundance" in the visual and material culture of Thai Buddhism can also help explain the presence and imagery of the glass paintings in these monastic settings. In early nineteenth-century Siam, the China trade was a source of great wealth for those who administered it. When the junks came sailing back up the Chao Phraya River, laden with commodities, they would convert into floating shops right where they were anchored, and shoppers could paddle over on their private boats to browse numerous little luxuries. ${ }^{44}$ Glass paintings were by no means the only imports from the China trade that were incorporated into Thai temple art and architecture: the large concrete statues of Chinese figures and animals that reportedly served as ballast for the trading ships still crowd the courtyards of 
many Bangkok monasteries, and other imported goods that found their way into temple structures included great quantities of tiles, ceramics, and various other building materials.

What set the glass paintings apart was that they were not only a product of the extensive and profitable Sino-Siamese commerce, they had the ability to reference it directly through their imagery, like the Wat Pho set featuring views of Canton, Macau, and ships traversing the Pearl River Delta. But the principle of "abundance" is perhaps best communicated through the glass paintings with decorative themes, bird and flower compositions and the auspicious arrangements that the Thais termed "Chinese altar tables." The significance of the latter design was thoroughly altered by its translation into Thai mural paintings, losing any messages that might have been implicit in the original rebus-like arrangements of punning objects and instead multiplying them into an exuberant assortment of luxuries (see Figures 7 and 15). But, as one might argue about Thai Buddhism more generally, in these mural designs materialism served a spiritual purpose: with the tables reconstrued as altars, everything upon them could be interpreted as an offering. ${ }^{45}$ In this manner, the "Chinese altar tables" design, whether in the glass paintings or the murals that resemble them, was able to reflect the visual aesthetic of abundance and accretion within the temples themselves and on their real altars.

Thai Adaptations of Chinese Glass Paintings

Neither the creation of reverse paintings on glass nor the practice of hanging framed paintings over the windows, doors, or internal columns of temple buildings became widespread in central Siam following the Third Reign, but there are several examples that are worthy of mention, and suggest further avenues of exploration. 
The Chapel of the Emerald Buddha (Wat Phra Kaew) that adjoins the Grand Palace contains a rich trove of glass paintings in unusual formats and styles that raise new questions. Flanking the base of the altar to the left and right sides, large standing screens--almost in the form of cubicles--contain multiple panels of Chinese painted glass with an assortment of images juxtaposed seemingly at random, including bird-and-flower, "assorted treasures," and narrative scenes probably from Romance of the Three Kingdoms. It is difficult to say if these screens were made in China and imported in their current form or else assembled locally from pre-existing glass paintings, but the impracticality of shipping such bulky yet exquisitely fragile structures and the arbitrariness of the juxtaposed imagery argues for the latter possibility.

Above each window and door in Wat Phra Kaew is a trio of paintings that portray the Buddha in various postures and attitudes: they are Thai in style, but appear from the way the pigments have weathered to be painted on glass (see Figure 5). "They are pictures painted on the back of mirrors," confirms a book published by the Bureau of the Royal Household, but it does not specify where or when they were made ${ }^{46}$ One possibility is that that glass painting techniques were borrowed for Buddhist content by local artisans; the other is that Thai templates were sent to China to request a custom-made set of images. Chinese reverse glass paintings that incorporated mirrored glass were commonplace and frequently imported by Western countries (several examples can be seen at the Peabody-Essex Museum), and some lingering patches of luster on the Posayachinda paintings suggest that they, and by extension their counterparts at Wat Kanlayanamit, might once have been mirrored (see Figures 16 and 17). The distinctive black backgrounds of the bird and flower paintings at Wat Suwannaram might also be explained by the oxidation of a once-mirrored surface (see Figure 19). 
Both the ordination and assembly halls of Wat Suthat, another grand and important temple, contain trios of framed paintings over the windows and doors that resemble Thai-style paintings on glass of scenes and creatures from the Ramakian รามเกียรติ์, the Thai version of the Ramayana (see Figure 5). However, close inspection suggests that they were painted not directly on glass but on very thin paper under glass--either that, or some flaw in the process has caused the pigments to peel away from the glass in sheets, wrinkling in places and rotting at the edges, and even becoming dislodged in large sections (Figure 20). ${ }^{47}$ The sure hands behind the imagery and text raise the possibility that this set was more likely painted, and the inscriptions almost certainly written, by Thai artists, rather than a Chinese workshop copying Thai patterns.

Wat Hong Rattanaram and Wat Dusitaram also have trios of framed paintings over the windows and doors, again Thai style images, although in this case they appear to be a mixture of jataka narratives, mythological figures, and scenes from the Buddha's life. Both King Nangklao and his successor, King Mongkut (r.1851-1868) contributed to renovations of these temples, so the Thai framed paintings were most likely made and installed either during or shortly after the period when the popularity of Chinese glass paintings had peaked..$^{48}$ There may have been a brief trend for making Thai-style framed pictures on the Chinese model just before the surge of Western cultural influences that dominated the latter half of the nineteenth century.

Wat Rakhang and Wat Prot Ket Chettharam contain sets of framed paintings that vary yet further in substance and style from Chinese precedents, demonstrating new knowledge of EuroAmerican artistic conventions. Those at Wat Rakhang depict scenes from the Buddha's life, together with a set of six views, hung together in two trios, of famous Buddhist sites in Thailand and Burma (Figure 21). It is easy to perceive that (at least in some cases) these pictures are under glass, but not painted on it, because in some cases the glass pane in front has slipped or gone 
askew, revealing the painting's ground to be a separate layer underneath. The material of the ground is uncertain, though it appears to be sturdier than that used at Wat Suthat. The figures in the scenes from the Buddha's life are adapted from classical iconographic poses and representational conventions, in a flat compositional style enlivened with hints of modeling and drapery. The backgrounds demonstrate a rudimentary but competent knowledge of Western brushwork, and also employ perspective, occasionally over-exaggerated.

Wat Prot Ket Chettharam displays an unusual set of framed paintings produced with tempera pigments on teak panels, although some of the images presently on view appear to be mechanical reproductions of originals that were stolen. ${ }^{49}$ The origins and artists of these paintings are unknown, although they were evidently made locally by one or more painters who were familiar with Thai design yet also intrigued by European architecture and pictorial conventions. ${ }^{50}$ It may be significant that they share some qualities in common with the innovations introduced by Khrua In Khong, a painter who became renowned during the reign of King Mongkut (1851-1868) for his murals at Wat Bowonniwet and Wat Boromniwat.

Initial observations of the framed paintings at the monasteries described above suggest that after the China trade waned in the mid-nineteenth century and glass paintings ceased to be a popular item of import, there was a shift to using paintings designed and produced locally. They were still hung in the same manner as the Chinese paintings had been, typically in gilt frames, often in trios, over the windows and doors of temples, but the source of inspiration for medium and style gradually changed from Chinese glass paintings to European art. This parallels the broader shift of cultural paradigms in Siam: the increasing presence of Europeans and Americans in Siam and the 1851 succession of King Mongkut, who studied Western culture with the same fervor that his predecessor had traded with China, meant that new fashions and ideas began to be 
drawn from occidental sources. These new sources of influence and inspiration did not fully replace but rather merged and combined with what had come before. If Thai Buddhism and its visual culture is characterized by accretion, this is because it is loathe to discard the material fabric already established in temple settings. New donations add to those that came before, and the pious clutter attests to both a history of rich patronage and the spiritual ethos of abundance. 
${ }^{1}$ Justin McDaniel, The Lovelorn Ghost and the Magical Monk: Practicing Buddhism in Modern Thailand (NY: Columbia University Press, 2011), 67. A particularly incisive critique by McDaniel of the tendency for much contemporary scholarship to overlook the significance of this "abundance" occurs on page 21: "Theravada Buddhism as it has been studied by scholars of religion has been depicted as a monastic movement that is desperately trying to stave off commercialism and materialism. This is part of the general Protestant devaluing of materiality that is often foisted onto Buddhist traditions. However, monks and devout Thai Buddhists are not victims of the trappings of a material world but are often the greatest purveyors of stuff." ${ }^{2}$ John Clark, Modern Asian Art (Honolulu: University of Hawaii Press, 1998), 39. See also Jessica Lee Patterson, "Temples of Trade: Chinese Art in Bangkok" (Ph.D. dissertation, University of California, Berkeley, 2009), 81-100.

${ }^{3}$ For more information on European traditions of reverse glass painting, see Frieder Ryser, Reverse Paintings on Glass: The Ryser Collection, translated by Rudy Eswarin (Corning, NY: Corning Museum of Glass, 1992).

${ }^{4}$ Numerous examples of glass paintings based on published prints may be seen in Wolfgang Steiner, Hinterglas und Kupferstich / Reverse Paintings on Glass (Munich: Hirmir Verlag, 2004).

${ }^{5}$ Ryser, Reverse Paintings on Glass, 31-2.

${ }^{6}$ Margaret Jourdain and R. Soame Jenyns, Chinese Export Art in the Eighteenth Century (London: Country Life Limited, 1950), 34.

${ }^{7}$ Although rarely put on display in museums, it seems that more might lurk in their 
storerooms. Rosalien van der Poel, a researcher in Leiden, has recently assembled a valuable inventory of Chinese export paintings, including some on glass, that she located in a number of collections throughout the Netherlands.

${ }^{8}$ In addition to works cited elsewhere in this article, the following are helpful resources on this topic: Alfred Tamarin and Shirley Glubok, Voyaging to Cathay: Americans in the China Trade (NY: The Viking Press, 1976); Christina H. Nelson, Directly From China: Export Goods for the American Market, 1784-1930 (Salem: Peabody Museum, 1985); Craig Clunas, Chinese Export Art and Design (Victoria and Albert Museum, 1987); Carl L. Crossman, The Decorative Arts of the China Trade: Paintings, Furnishings, and Exotic Curiosities (Antique Collectors Club, 1991); and Views of the Pearl River Delta: Macau, Canton and Hong Kong (Urban Council of Hong Kong, 1996).

${ }^{9}$ Donald M. Stadtner has several examples of early twentieth-century Burmese glass paintings in Sacred Sites of Burma: Myth and Folklore in an Evolving Spiritual Realm (Bangkok: River Books, 2001). Wat Chong Klang [alternately Wat Chon Klang or Jong Klang] in Mae Hong Son, a city in the far northwest of modern Thailand (formerly the kingdom of Lanna), houses a very rich trove of 180 Burmese paintings on glass. These came to international attention after many were damaged in a 2004 earthquake, and Texas artist Judy Jensen raised funds through Kickstarter to replace them. The scholars Catherine Raymond and Alan Potkin have been researching and speaking about this set of paintings.

${ }^{10}$ Clark, Modern Asian Art, 49-69.

${ }^{11}$ One notable incident which prefigured the present-day disputes between the US and China over intellectual property rights occurred with a Philadelphia merchant who owned one of Gilbert Stuart's famous portraits of George Washington commissioned a hundred copies on glass 
to be made in China, a breach of contract for which Stuart successfully sued him in 1802 . See Owen A. Aldridge, The Dragon and the Eagle: The Presence of China in the American Enlightenment (Detroit: Wayne State University Press, 1993), 114. In fairness, even the contemporary Chinese art copying workshops have begun to receive attention, so democratic are today's art historians: Winnie Wong has recently published Van Gogh on Demand: China and the Readymade (Chicago: University of Chicago Press, 2013).

12 The Chapel of the Emerald Buddha (Wat Phra Kaew) was built together with the Grand Palace from 1782-1784 when Rama I transferred the Thai court across the river from Thonburi to Bangkok. Rama III made significant artistic modifications to the temple, such as his installation in 1841 of the two large standing Buddhas on either side of the altar that were dedicated to the two previous monarchs, his father and grandfather. The wall murals date from the First Reign, but I have not yet seen any speculations on when the Thai-style glass paintings of scenes from the Buddha's life were installed. Wat Suthat was constructed in 1807, though Rama III also contributed materially to the site and held a dedication ceremony for it in 1843 .

${ }^{13}$ For examples of the subsequent Westernizing trend, see the murals from the 1850 s by Khrua In Khong at Wat Borom Niwat in Bangkok, or the Gothic-style architecture of Wat Niwet Thammaprawat, a temple built in the 1870s at the royal retreat of Bang Pa-In.

${ }^{14}$ I have assembled this list from my own investigations in the field. Bangkok's monasteries are numerous, and there may well be further examples that remain undiscovered. According to the table of information compiled by Wannipha na Songkhla in Jitrakam Thai prapheni จิตรกรรมไทยประณิ [Traditional Thai painting], set 1, volume 1 (Bangkok: Silpakorn University, 2533 [1990]), 110-127: Wat Phra Chetuphon (Wat Pho) was built in 1768 and dedicated in 1800; Wat Thepthidaram was built in 1836 and dedicated in 1839; no firm dates are listed for Wat 
Nangnong; Wat Kanlayanamit was built in 1825 and dedicated in 1836; no date of construction is given for Wat Arun, but it was dedicated in 1824; and Wat Phakhininat and Wat Suwannaram were built before the Bangkok Era and dedicated in the First Reign (though both enjoyed major renovations in the Third Reign). Other sources provide different dates, for instance, Prawat wat thua ratcha anajak ประวัติวัดทั่วราชอาณาจักร [History of temples throughout the kingdom], volume 1 (Bangkok: Rong Phim Satsana, 2525 [1982]), 207, states that Wat Thepthidaram was dedicated in 1845 . It might be the case that the 1839 and 1845 dates are not a discrepancy but in fact specify two different ceremonies, because the sources use slightly different terms, phukphat sima ผูกพัทธสีมา for the 1845 ceremony and wisungkham sima วิสุงคามสีมา for the 1839 ceremony. The former is defined as a "ceremony designating the area for conducting sangha activities; ceremony designating the area of the ubosot," and the latter as a "monastery that has received acknowledgment from the government by means of a royal decree distinctly fixing and proclaiming the area for conducting ubosot and sangha activities." (Definitions from Manit Manitcharoen, Phajananukrom Thai พจนานุกรมไทย [Thai Dictionary] (Bangkok: Ruamsan Co., Ltd., 2535 [1992]), 628; 888.) However, since both terms refer to a formal installation or recognition of the sima stones that form the boundary of the ordination hall's sacred enclosure, and it seems improbable that a phukphat sima would be necessary after the wisungkham sima has already taken place, it is also possible that the sources conflict about precisely when the same sima dedication ceremony occurred. Moreover, even the firmest dates only provide a partial story, because the history of these temples involves numerous interventions in the form of restoration, renovation, redesign, and renaming. Although the historical record remains obscure or conflicted in some cases, one factor that each of these seven monasteries has in common is 
that they each experienced significant patronage by King Nangklao and/or members of his family and officials of his court during the Third Reign (1824-1851).

${ }^{15}$ A vivid example of this principle from a later reign is described in Nigel Brailey, Two Views of Siam on the Eve of the Chakri Reformation: Comments by Robert Laurie Morant and Prince Pritsdang (Arran, Scotland: Kiscadale Publications, 1989), 54, quoting Prince Pritsdang: "Not long ago the King took a fancy to making a collection of rare China in sets and suites to match according to the Chinese fashion which forms a tableau on a series of tables. The whole official world goes about the country in search of rare china; they would divest themselves of their high rank and haughtiness and stoop low to beg, borrow, purchase and use threats to obtain the object of their wishes from the poor and the rich. Many of them have been made noble by their successs in finding the proper pieces."

${ }^{16}$ The story is widely circulated, and detailed accounts can be found in books published by the temple, such as Wat Ratcha Orotsaram Ratchaworawihan วัดราชไอรสาราม ราชวรวิหาร (Bangkok: Wat Ratcha Orot, 2006), 14-15.

${ }^{17}$ A letter from a foreign resident of Bangkok dated May 30, 1838 describes observing the construction of the large reclining Buddha: "Some thousands of bushels of lime, molasses, quicksilver, etc., etc., have been put into the composition--so that it may be as hard as marble in the end.... This is built by the king, and is different from any thing of the kind in the kingdom." See The Missionary Herald 35:4 (April, 1839): 134-136. The writer was evidently unaware of the similar but smaller reclining Buddha statue that the same king had installed in the 1820s in the assembly hall (wihan) of Wat Ratcha Orot. There is no question that the reclining Buddha at Wat Ratcha Orot is original to the building, as the unusually long and narrow interior of the hall 
appears to have been designed specifically to accommodate it, much like the corresponding structure at Wat Pho.

${ }^{18}$ Phanuphong Laohasom and Chaiyot Itworaphan, Plian phuen, plaeng phap, prap rup, prung lai เปลี่ยนพื้น แปลงภาพ ปรับรูป ปรุงลาย [Change the foundation, alter the picture, adjust the form, prepare the pattern] (Bangkok: Muang Boran, 2549 [2006]: 67-76.

${ }^{19}$ My dissertation offers a more thorough discussion of the structure of the Wat Ratcha Orot murals and their resemblance to duobaoge cabinets and ch'aekkori screens. See "Temples of Trade: Chinese Art in Bangkok, 1824-1851" (PhD diss., University of California, Berkeley, 2009), 110-117. For more information on the Korean screen paintings, see Sunglim Kim, "Chaekgori: Multi-dimensional Messages in Late Joseon Korea," Archives of Asian Art 64:1 (2014): 3-32.

${ }^{20}$ Phanuphong and Chaiyot, Plian Phuen, plaeng phap, 68.

${ }^{21}$ John Crawfurd, Journal of an Embassy from the Governor-General of India to the Courts of Siam and Cochin-China; Exhibiting a View of the Actual State of Those Kingdoms. Vol. I (London: Henry Colburn and Richard Bentley, 1830), 202-3.

${ }^{22}$ See Steiner, Hinterglas und Kupferstich, in which one hundred German glass paintings are paired with the engravings of which they are copies.

${ }^{23}$ Excerpted from a letter of 22 December, 1825. The audience took place on 16 December, 1825. Henry Burney, et al., Burney Papers, vols. 1-4 [1825-1831] (Bangkok: Vajiranana National Library, 1910-1912), vol. 1, 47.

${ }^{24}$ Carl L. Crossman, The China Trade: Export Paintings, Furniture, Silver \& Other Objects. (Princeton: The Pyne Press, 1972), 123-124. 
${ }^{25}$ Josef Vydra, Folk Painting on Glass, translated by Helen Watney (London: Artia/Spring Books, 1967 [1955]), 21.

${ }^{26}$ Vydra, Folk Painting on Glass, Color Plate III. Considering that Vydra published his book over half a century ago, one hopes that the identity of the picture has already been discovered and the label amended.

${ }^{27}$ Steiner, Hinterglas und Kupferstich, 11-12.

${ }^{28}$ The ordination hall of Wat Pho has sixteen interior columns, with three paintings hung on each column, yielding a total of forty-eight paintings. However, one of the trios me that one of the sixteen trios (located on the rearmost column behind the altar on the Buddha's left) appears to be a reproduction in newer frames of the trio on the column next to it. Unfortunately, the dim lighting conditions and constricted space behind the altar made it impossible to determine this for certain or to come away with clear photographic evidence. In support of this possibility is the fact that a lavish official volume about Wat Pho that describes every form of art in the ordination hall, although it devotes a generous spread of sixteen pages providing color photographs of each of the glass paintings and preserving the arrangement in which they are hung, includes only fifteen of the trios. On the suspicion that these are the only ones to survive of the original set, my analysis is limited to these forty-five. See Bunchob Maitreechitt, ed., The Ubosot of Wat Pho (Bangkok: Amarin Printing and Publishing Co., Ltd., 1999), 226-241.

${ }^{29}$ For an image of the sewing table, see Views of the Pearl River Delta: Macau, Canton and Hong Kong (Urban Council of Hong Kong, 1996), 77.

${ }^{30}$ Santi and Nawarat Phakdikham have published a book-length study of several examples of Three Kingdoms imagery that appeared in extensive sets of mural paintings and stone carvings in nineteenth-century Bangkok. See Santi and Nawarat Phakdikham, Samkok: Sinlapakam Jin Wat 
Thai nai Bangkok สามก๊ก ศิลปกรรมจีนวัดไทยในบางกอก [Samkok: Chinese Art in Thai Temples in Bangkok]. Bangkok: Matichon, 2549 [2006].

${ }^{31}$ Dates for the temple come from Wannipha na Songkhla, Jitragam Thai praphenee, 116. Note 11, above, describes conflicting dates for when the sima stones were ceremonially dedicated, but the Thai tradition that the poet Sunthorn Phu was ordained at Wat Thepthidaram in 1840 suggests that the ordination hall was complete and ritually functional by that time.

${ }^{32}$ An examination of the backs of the paintings might reveal valuable clues about their specific workshop origins, as has been the case with a number of the glass paintings in museum collections. Neither Jitrakam Thai prapheni nor Prawat wat thua ratcha anajak (see note 11) provide specific dates in their entries for Wat Nangnong, but a book published by the temple itself states that it was originally a common temple built in the Ayutthaya era, but that in the process of his extensive renovations, Rama III elevated it to the status of a royal temple in 1841. See Wat Nangnong วัดนางนอง (Bangkok: Wat Nangnong Worawihan, 2550 [2007], 6.

${ }^{33}$ It is possible that more specific information about the origins of the paintings, such as the workshops or ateliers from which they were sourced, could be determined by a close physical examination of the backs of the paintings, in case they are marked or inscribed in some way. No such marks or signatures are visible on the front. However, I am not aware of anyone who has made such an examination, and have been hesitant to petition the monasteries to bring these extremely fragile paintings down from their high perches, lest more of them be broken and lost in the process. This may be criticized as scholastic cowardice, but it is a reasonable caution given that there are no museum-type protocols in place for the handling or preservation of these works. 
${ }^{34}$ Santi Phakdikham explores the theme of royalty so pervasive in the decoration of this temple can be found in "Wat Nangnong: A Temple of King of Kings," Muang Boran 32:3 (JulySeptember, 2006): 32-63.

${ }^{35}$ Although they do not fit into this study, glass paintings can also be found in the Phra Thinang Wehat Chamrun, a distinctively Chinese-style mansion at Bang Pa-In that was constructed for King Chulalongkorn (Rama V, r.1868-1910) in the late nineteenth century by resident Chinese merchants.

${ }^{36}$ Stanley Tambiah, World Conquerer and World Renouncer (Cambridge: Cambridge University Press, 1977). See page 89 regarding the Thai inheritance of elements of the Khmer devaraja cult, and 96-97 for language and ritual that treats the king as the equivalent of a bodhisattva. For information on contemporary spirit cults devoted to the spirits of historical royalty, some quite recently deceased, see Pattana Kitiarsa, Mediums, Monks, \& Amulets (Chiang Mai: Silkworm Books, 2012), 28.

${ }^{37}$ The specific dates for Wat Phakhininat's construction and renovation remain somewhat conjectural. Originally named "Wat Bangjak," it dates from the late Ayutthaya era but was renovated by a princess of the First Reign (1782-1809). In the Third Reign (1824-1851), King Nangklao sponsored another major restoration, which included changing the temple's name to "Wat Phakhininat" and elevating its status from a common to a royal monastery. It is widely believed that the Chinese-style murals in the ordination hall date from this era, and thus it is likely that the Chinese glass paintings hanging just above them were installed during the same restoration. The funeral volume for a former abbot of Wat Phakhininat, a book published by the monastery itself, acknowledges that although we do not possess documentary evidence specifying the precise nature of King Nangklao's interventions, his extensive patronage of this 
temple, including its change of name and status, is substantiated in a contemporary poem by the courtier Nai Mee Mahatlek. In the poem, Wat Phakhininat is listed alongside other monasteries that King Nangklao also renovated, such as Wat Suwannaram and Wat Arun, that were likewise adorned with sets of Chinese glass paintings. See Prawat Wat Phakhininat Worawihan lae botniphon khong Phraratcha Mongkhonmuni ประวัติวัดภคินีนาถวรวิหาร และ บทนิพนธ์ของพระราชมงคลมุนี [The history of Wat Phakhininat and the writings of Phraratcha Mongkhonmuni] (Bangkok: Wat Phakhininat, 2551 [2008]), 7.

${ }^{38}$ Terese Tse Bartholomew, Hidden Meanings in Chinese Art (San Francisco: Asian Art Museum, 2006).

${ }^{39}$ Characters in the earliest sections are painted fluently, but in more recent times this expertise has been lost. Having witnessed a restoration of the paintings in progress in 2007, I observed that the young Thai artists who were repainting the murals typically lacked Chinese literacy and, in some cases, went so far as to invent marks vaguely resembling Chinese characters to fill in lacunae.

40 "Beautiful friend" is a literal translation of the root words (at least in their Thai derivations), but within Buddhism, the Pali term kalyanamitta had acquired the deeper significance of a spiritual mentor, an association of which the pious King Nangklao was probably aware. The Kanlayanamit family has expanded greatly since the time of its founder, and the surname is now widespread. Wannipha na Songkhla, Jitrakam Thai prapheni, 120, specifies 1825 as the date for the initial construction of Wat Kanlayanamit, and 1836 as the date of its formal dedication.

${ }^{41}$ Several pages are devoted to a description of the Posayachinda residence in Ronald G. Knapp, Chinese Houses of Southeast Asia: The Eclectic Architecture of Sojourners and Settlers (Tokyo: Tuttle Publishing, 2010), 222-227, and it was in the photographs on page 226 that I originally 
spotted the glass paintings and recognized their resemblance to those at Wat Kanlayanamit. In June 2011 I was able to see the paintings in person. I wish to convey my thanks to Poosak Posayachinda for graciously sparing the time to show me around his ancestral home.

${ }^{42}$ In addition to the two temples discussed above, I have found five other examples to date of "Chinese altar tables" being used as a primary mural design: the ordination halls of Wat Sam Phraya, Wat Nak Prok, Wat Chantaram, a small assembly hall at Wat Bowonniwet, and a very recent renovation of an assembly hall at Wat Phanan Choeng in Ayutthaya that was deliberately modeled on Wat Ratcha Orot. There is vague anecdotal evidence that the ordination hall of Wat Kanlayanamit was once similarly painted--the art historian Santi Leksukhum claimed that an old monk once assured him of such, but these murals have completely vanished apart from a few surviving square inches that are sufficient to demonstrate only that something Chinese in theme once occupied the space. See Santi Leksukhum, Jitrakam Thai, samai rachakan thi sam: khwamkhit plien kansadaeng auk ko plien tam จิตรกรรมไทย สมัยรัชกาลที่๓ ความคิดเปลี่ยน การแสดงออก ก็เปลี่ยนตาม [Thai Painting in the Third Reign: As Thoughts Change, Expressions Change Accordingly] (Bangkok: Muang Boran, 2005), 171. Finally, another example can be found in the Ho Phra That Monthian of the Grand Palace, though this building is unfortunately closed to the public.

${ }^{43}$ McDaniel, The Lovelorn Ghost, 164.

${ }^{44}$ Frederick Arthur Neale, Narrative of a Residence in Siam (London: Office of the National Illustrated Library, 1852), 173-175.

${ }^{45}$ This transformation of significance from encoded rebus to implied worship is explicitly visible in Phanuphong and Chaiyot's discussion of the mural paintings at Wat Ratcha Orot, where they speculate that the "altar table" imagery might have the same meaning as the older thep chumnum 
[congregating celestials] pattern that was commonly painted on the upper walls of Thai temples in the early Bangkok period. See Phanuphong and Chaiyot, Plian phuen, plaeng phap, 71. ${ }^{46}$ The term krajok that I have translated "mirrors" can also mean simply "glass." I chose to specify "mirrors" because the paintings do appear to have incorporated mirrored glass, although now much weathered. In the reproductions these background areas appear as mottled grey, but seen in person, something of their old luster can still be detected. See Suchin Thongyuak, "The Painting of the Attitudes of the Lord Buddha," in The Mural Painting of the Life of the Lord Buddha in the Ubosot of the Temple of the Emerald Buddha, (Bangkok: Bureau of the Royal Household, 2004), 144.

${ }^{47}$ In this painting of a yak (ogre from Thai mythology, derived from the Sanskrit yaksha), it is easy to see that the pigments are in a separate layer that does not adhere to the glass: in the upper left corner of the painting, a whole section containing the conical headpiece and one of the arms has come loose and fallen at an angle, truncating the face and obscuring part of the thigh on that side.

${ }^{48}$ Rattanakosin Painting (Bangkok: Fine Arts Department, 2525 [1982]) dates the framed paintings at Wat Hong Rattanaram to the Fourth Reign (1851-1868).

${ }^{49}$ A book published by the temple refers to the theft of foreign-style paintings in the assembly hall, although it does not specify when this occurred, how many were stolen, or confirm whether the paintings on view presently are the reproductions that they appear to be. See Wat Prot Ket Chettharam วัดโปรดเกศเชษฐาราม (Bangkok: Wat Prot Ket Chettharam, 2543 [2000], 44. Page 72 contains more speculations but few concrete facts about the "foreign-style" paintings and their unknown origins. Rattanakosin Painting, 258-259, specifies the medium as tempera on teak and asserts that the unknown artist was Thai. 
${ }^{50}$ A number of the compositions appear to be very free adaptations of European works, almost certainly through a lineage of one or more intervening copies. The source for one composition can be identified as The Fountain in the Place du Châtelet, Paris, painted by French artist Etienne Bouhot in 1810. Rattanakosin Painting, 137, provides a full-page reproduction of this image. 